\title{
KERAGAMAN DAN KEMELIMPAHAN COLLEMBOLA SERTA ARTHROPODA TANAH DI LAHAN SAWAH ORGANIK DAN KONVENSIONAL PADA MASA BERA
}

\author{
Indriyati $^{1}$ dan Lestari Wibowo ${ }^{1}$
}

\begin{abstract}
The diversity and abundance of Collembola and soil arthropods in organic and conventional lowland field at fallow time. As ecosystem components, Collembola and arthropods are important in keeping the ecosystem stability. Beside its role as the decomposer, Collembola also takes part as the alternative food for arthropod predators. This research was aimed to gather information on the diversity and abundance of Collembola and arthropods in organic and conventional lowland field at fallow time. The sampling was done using pitfall trap and Berlese funnel. The results showed that: (1) the abundance of Collembola in organic lowland field was higher than that of in the conventional lowland field but the diversity of Collembola in the organic lowland field was not different from that of in the conventional field; (2) Entomobryidae was the family with the highest abundance; and (3) the diversity and abundance of soil arthropods were relatively greater in organic lowland field than that of in the conventional lowland.
\end{abstract}

Key words : diversity, collembola, arthropods, organic lowland field

\section{PENDAHULUAN}

Sistem pertanian organik kini semakin banyak dikembangkan sebagai bagian dari upaya penerapan pertanian yang ramah lingkungan. Dalam sistem pertanian organik tidak digunakan bahan-bahan kimia sintetik seperti pestisida, pupuk sintetik, atau zat pemacu pertumbuhan tanaman. Masukan atau bahanbahan yang digunakan dalam sistem pertanian organik adalah bahan organik alami dan diperoleh dari lingkungan sekitar. Sejumlah manfaat yang amat berarti dari penerapan pertanian organik tergambar dari berbagai penelitian, meliputi aspek-aspek kesehatan pangan, kesehatan lingkungan, perbaikan terhadap struktur tanah, siklus mineral, dan kesuburan lahan (Trewavas, 2007). Selain hal tersebut penerapan sistem pertanian organik juga tampak mendorong stabilitas agroekosistem dan kelestarian lingkungan (Anggoro, 2003; Trewavas, 2007).

Di dalam ekosistem yang stabil umumnya terdapat organisme dengan diversitas yang tinggi. Berbagai jenis organisme dalam ekosistem berperan penting dalam menjaga stabilitas ekosistem melalui interaksinya yang kompleks dalam jaring-jaring makanan (Odum, 1971; Krebs, 1985). Organisme yang sering dijumpai banyak berasosiasi dengan tanah dan tanaman pada agroekosistem di antaranya adalah kelompok Collembola dan jenis-jenis arthropoda lainnya. Collembola selama ini telah banyak dikenal, tetapi penelitian tentang peran dan keberadaannya perlu terus dikembangkan.

Collembola umumnya dikenal sebagai organisme yang hidup di tanah dan memiliki peran penting sebagai perombak bahan organik tanah. Dalam ekosistem pertanian Collembola terdapat dalam jumlah yang melimpah. Collembola pada ekosistem pertanian merupakan pakan alternatif bagi berbagai jenis predator (Greenslade et al., 2000). Sebagai mangsa atau pakan alternatif bagi predator, Collembola memberi kontribusi dalam menjaga keberlangsungan hidup predator yang menjadi musuh alami berbagai jenis hama. Peran ini sangat penting terutama pada saat kepadatan populasi serangga hama rendah misalnya pada masa setelah panen atau masa bera (Ponge et al., 2003; Kanal, 2004).

Kondisi ekosistem sawah saat masa bera, pada umumnya cenderung menekan kepadatan populasi serangga hama. Keadaan demikian akan mendorong predator mencari mangsa alternatif. Jika Collembola terdapat dalam jumlah yang melimpah dapat mendorong atau mempertahankan kelangsungan hidup predator sampai musim tanam berikutnya (Ponge et al., 2003; Kanal, 2004). Kemelimpahan Collembola sangat ditentukan oleh sistem pertanian yang diterapkan pada lahan tersebut. Sistem pertanian dengan aplikasi pestisida secara berlebihan dapat menekan populasi Collembola. Sebaliknya, sistem pertanian yang ramah lingkungan seperti sistem

\footnotetext{
${ }^{1}$ Jurusan Proteksi Tanaman, Fakultas Pertanian, Universitas Lampung Jl. Prof. Soemantri Brodjonegoro No. 1 Bandar Lampung 35145
} 
pertanian organik akan menciptakan keadaan yang mendukung bagi kelangsungan hidup Collembola.

Penelitian ini bertujuan untuk mengetahui keragaman dan kemelimpahan Collembola serta arthropoda di lahan sawah pertanian organik dan konvensional pada masa bera.

\section{METODE PENELITIAN}

Penelitian ini dilaksanakan pada bulan Juni sampai Agustus 2006 (pada saat sawah masa bera) di areal persawahan pertanian organik dan pertanian konvensional di Kecamatan Pagelaran Kabupaten Tanggamus Lampung. Lahan pertanian organik yang dipilih adalah lahan yang selama enam tahun terakhir secara terus menerus digunakan untuk pertanian organik.

Pengambilan sampel dilakukan secara sistematis pada tiga petak sawah pertanian organik dan tiga petak sawah konvensional. Setiap petak sawah berukuran $20 \times 25 \mathrm{~m}$. Pengambilan sampel Collembola dan arthropoda tanah lainnya dilakukan dengan perangkap pitfall trap dan corong Berlese.

Pada setiap petak, pemasangan pitfall dilakukan pada 10 titik sampel yang tersebar pada posisi diagonal petak. Dengan demikian jumlah pitfall yang dipasang masing-masing sebanyak 30 buah baik pada sawah organik maupun pada sawah konvensional. Pitfall diisi dengan $80 \mathrm{ml}$ alkohol $70 \%$ dan diberi naungan plastik mika, dipasang selama tiga hari. Arthropoda tangkapan dipindahkan ke dalam tabung koleksi yang berisi alkohol 70\%. Adapun sampel tanah untuk perangkap Berlese dipersiapkan sebanyak dua sampel per petak, masing-masing $500 \mathrm{ml}$ tanah dan serasah yang ada di permukaan tanah seluas $1 \mathrm{~m}^{2}$. Sampel tanah tersebut diletakkan di dalam corong Berlese untuk proses pemerangkapan selama enam hari. Collembola dan arthropoda yang diperoleh ditampung dalam tabung koleksi dengan alkohol 70\%,

Pengamatan dan identifikasi terhadap Collembola dan arthropoda hasil tangkapan dilakukan di Laboratorium Hama Arthropoda Jurusan Proteksi Tanaman Fakultas Pertanian Universitas Lampung hingga Desember 2006.

Identifikasi Collembola dilakukan dengan Greenslade et al. (2000), sedangkan identifikasi arthropoda dilakukan dengan Borror et al. (1992) dan Scott \& Stojanovich (1982).
Kemelimpahan Collembola dan arthropoda diperoleh dari jumlah Collembola dan arthropoda yang didapat pada masing-masing jenis lahan sawah bera (spesimen hasil tangkapan pitfall dan Berlese ). Nilai rata-rata Collembola dan arthropoda yang tertangkap pada pitfall trap dari lahan sawah konvensional dan organik diuji dengan uji t pada taraf nyata 5\% dan 1\%.

Data jumlah individu setiap famili digunakan untuk menghitung jumlah famili relatif (JFR) dan diberi simbol $\mathrm{p}_{\mathrm{i}}$. JFR adalah jumlah individu dalam suatu famili dikali $100 \%$ dibagi dengan total jumlah individu (total tangkapan dari 36 perangkap). Keragaman Collembola dan arthropoda dihitung dengan indeks diversitas Shannon-Wiener (Krebs, 1985) : $H^{\prime}=-\sum p_{i} x \ln p_{i}$, dengan $H^{\prime}=$ indeks keragaman, $\mathrm{p}_{\mathrm{i}}=$ proporsi atau jumlah famili relatif ke-i. Adapun kemerataan banyaknya individu pada tiap famili dihitung dengan indeks kemerataan (evenness) (Odum, 1971; Price, 1997) sebagai berikut: $\mathrm{E}=\mathrm{H}^{\prime} / \ln \mathrm{S}$, dengan $\mathrm{E}=$ indeks kemerataan, $\mathrm{H}^{\prime}=$ indeks keragaman, $\mathrm{S}=$ jumlah jenis (dalam hal ini famili).

\section{HASIL DAN PEMBAHASAN}

\section{Keragaman dan kemelimpahan Collembola}

Hasil pengamatan menunjukkan bahwa Collembola yang tertangkap dengan perangkap pitfall sebanyak 7 jenis (famili) dari lahan sawah organik dan sebanyak 5 jenis dari lahan sawah konvensional. Adapun Collembola yang tertangkap dengan perangkap Berlese masing-masing sebanyak 3 jenis baik pada sawah organik maupun konvensional (Tabel 1).

Collembola yang tertangkap pada perangkap pitfall lebih beragam dibandingkan dengan yang tertangkap pada corong Berlese. Pada perangkap corong Berlese diperoleh tiga famili Collembola, dan ketiga famili ini adalah jenis yang terdapat baik pada perangkap Berlese maupun pitfall serta yang berasal dari lahan sawah organik maupun konvensional dengan kemelimpahan populasi yang lebih tinggi dibandingkan empat famili lainnya. Ketiga famili tersebut ialah Entomobryidae, Isotomidae, dan Hypogastruridae (Tabel 1, Tabel 2).

Penelitian Kanal (2004) pada lahan yang mendapatkan perlakuan rotasi tanaman, pemupukan serta pengaruh pergantian kondisi iklim tahunan juga mendapatkan dominasi jenis Collembola famili 
Tabel 1. Jenis Collembola yang tertangkap pada perangkap pitfall dan corong Berlese pada sawah organik dan sawah konvensional

\begin{tabular}{clcccc}
\hline & \multirow{2}{*}{ Famili } & \multicolumn{2}{c}{ Perangkap pitfall } & \multicolumn{2}{c}{ Corong Berlese } \\
\cline { 3 - 6 } No & $\begin{array}{c}\text { Sawah } \\
\text { Organik }\end{array}$ & $\begin{array}{c}\text { Sawah } \\
\text { Konvensional }\end{array}$ & $\begin{array}{c}\text { Sawah } \\
\text { Organik }\end{array}$ & $\begin{array}{c}\text { Sawah } \\
\text { Konvensional }\end{array}$ \\
\hline 1. & Entomobryidae & + & + & + & + \\
2. & Paronellidae & + & + & - & - \\
3. & Isotomidae & + & + & + & + \\
4. & Hypogastruridae & + & + & + & + \\
5. & Sminthuridae & + & + & - & - \\
6. & Dicyrtomidae & + & - & - & - \\
7. & Bourletiellidae & + & - & - & \\
\hline
\end{tabular}

Keterangan : + : ada; - : tidak ada

Tabel 2. Jumlah famili relatif (\%), indeks keragaman $\left(\mathrm{H}^{\prime}\right)$, dan indeks kemerataan (E) populasi Collembola yang tertangkap pada sawah organik dan konvensional

\begin{tabular}{cccc}
\hline & & \multicolumn{2}{c}{ Jenis Famili Relatif (\%) } \\
\cline { 3 - 4 } No & Famili & $\begin{array}{c}\text { Sawah } \\
\text { Organik }\end{array}$ & $\begin{array}{c}\text { Sawah } \\
\text { Konvensional }\end{array}$ \\
\cline { 3 - 4 } 1. & Entomobryidae & 50,9 & 47,6 \\
2. & Paronellidae & 13,2 & 11,7 \\
3. & Isotomidae & 26,1 & 7,2 \\
4. & Hypogastruridae & 8,3 & 29,1 \\
5. & Sminthuridae & 0,8 & 4,4 \\
6. & Dicyrtomidae & 0,2 & 0,0 \\
7. & Bourletiellidae & 0,6 & 0,0 \\
\hline \multicolumn{2}{l}{ Indeks Keragaman (H') } & & 1,35 \\
\hline Indeks Kemerataan (E) & 1,22 & 0,84 \\
\hline
\end{tabular}

Entomobryidae dan Isotomidae disamping famili Onichiuridae.

Famili Entomobryidae yang pada penelitian ini dijumpai dengan kemelimpahan tertinggi (Tabel 2) dikenal sebagai jenis Collembola yang banyak terdapat pada permukaan tanah, pada lapisan olah, maupun pada lapisan serasah. Collembola dengan bentuk yang ramping ini (slender springtail) diketahui memiliki perilaku sebagai pemakan jamur, liken, bakteri, dan juga pollen tumbuhan tertentu serta pengurai serasah organik (Anonim, 2007; Hadley, 2007). Bahkan karena seringnya ditemukan dalam populasi yang tinggi serta peranannya sebagai dekomposer yang efektif Entomobryidae banyak membantu siklus nutrien dalam tanah dan dinyatakan dapat menggambarkan status produktivitas lahan pada suatu habitat (Kanal, 2004; Hadley 2007). Sehubungan dengan itu Kanal (2004) juga menyatakan bahwa adalah penting secara periodik dilakukan pengamatan untuk memantau kemelimpahan Collembola dalam manajemen kesuburan tanah yang berkelanjutan.

Keragaman Collembola yang dinyatakan sebagai indeks Shannon-Wiener terlihat pada lahan konvensional sebesar 1,35 yang lebih tinggi dibandingkan pada lahan organik sebesar 1,22. Tampaknya kemerataan kemelimpahan diantara famili-famili yang lebih tinggi pada lahan konvensional memiliki kontribusi pada nilai indeks 
Shannon (Tabel 2). Namun demikian, pengujian terhadap rata-rata kemelimpahan Collembola yang ditemukan pada lahan organik lebih tinggi dibandingkan pada lahan konvensional (nilai $\mathrm{t}_{\text {hit }}=$ $7,54 * * ; t_{\text {tabel } \alpha .01}=2,45$ ). Pada lahan organik jumlah Collembola yang tertangkap rata-rata 76,03 ekor/pitfall, sedangkan pada lahan konvensional Collembola yang tertangkap rata-rata sebanyak 26,09 ekor/ pitfall (Tabel 3). Hal ini menunjukkan bahwa kemelimpahan Collembola pada lahan organik nyata lebih tinggi dibandingkan pada lahan konvensional. Diduga penggunaan insektisida yang intensif pada pelaksanaan budidaya tanaman padi pada lahan konvensional telah menekan kemelimpahan populasi berbagai jenis arthropoda termasuk Collembola. Endlweber et al. (2006) yang mengaplikasikan insektisida klorpirifos dan dimetoat melalui daun dan tanah mendapati adanya pengaruh yang signifikan dari kedua jenis bahan aktif insektisida tersebut dalam menekan kepadatan populasi Collembola, mengubah dominasi jenis, sungguhpun komposisi jenis dari Collembola tersebut tidak berubah. Sedangkan penelitian Fountain et al. (2007) menunjukkan bahwa aplikasi insektisida klorpirifos berakibat menurunkan keragaman jenis, kekayaan jenis dan kemerataan jumlah individu di dalam famili (jenis-jenis) Collembola yang dijumpai. Selain pengaruhnya terhadap Collembola, Fountain et al. (2007) juga melihat hal yang serupa terhadap laba-laba terutama jenis Lyniphidae walaupun keragamannya tidak berbeda. Insektisida berbahan aktif klorpirifos, dan juga yang berbahan aktif BPMC, tergolong sering digunakan pada kegiatan budidaya tanaman padi pada lahan sawah konvensional.

\section{Kemelimpahan arthropoda nir Collembola}

Selain Collembola, berbagai jenis arthropoda tanah juga tertangkap pada perangkap pitfall dan corong Berlese baik dari lahan sawah organik maupun konvensional. Pada lahan organik diperoleh 27 famili arthropoda nir Collembola, sedangkan pada lahan konvensional diperoleh 26 famili (Tabel 4).

Hasil penghitungan indeks keragaman arthropoda nir Collembola menunjukkan bahwa keragaman pada lahan organik $\left(H^{\prime}=2,753\right)$ lebih tinggi dibandingkan pada lahan konvensional $\left(\mathrm{H}^{\prime}=\right.$ 2,605). Demikian pula nilai indeks kemerataan pada lahan organik $(E=0,782)$ lebih tinggi dibandingkan pada lahan konvensional $(E=0,766)$. Adapun hasil uji t terhadap rata-rata jumlah arthropoda nir Collembola yang tertangkap pada kedua jenis lahan menunjukkan perbedaan yang sangat nyata (nilai $t_{\text {hit }}=3,31 * * ; t_{\text {tabel }}$ $\alpha_{\alpha} \quad 0,01=2,457$ ). Pada lahan organik jumlah arthropoda nir Collembola yang berhasil tertangkap rata-rata 22,43 ekor/ pitfall, sedangkan pada lahan konvensional rata-rata 17,73 ekor/ pitfall.

Lahan sawah organik pada masa bera ternyata merupakan habitat yang baik untuk hidup dan berbiak berbagai jenis arthropoda tanah. Pada lahan sawah organik tempat pengambilan sampel telah diterapkan sistem pertanian organik selama 6 tahun. Penambahan bahan organik berupa kompos pada sistem pertanian organik, dapat memperbaiki sifat fisik, kimia dan biologi tanah. Kandungan karbon dan nitrogen yang tinggi pada bahan organik merupakan sumber energi bagi mikroorganisme tanah (Trewavas, 2007). Dengan demikian lahan yang kaya akan bahan organik sangat mendukung pertumbuhan dan perkembangan berbagai jenis mikroorganisme dan

Tabel 3. Rata-rata kemelimpahan Collembola (ekor/ pitfall) yang tertangkap pada sawah organik dan konvensional

\begin{tabular}{clcc}
\hline No. & \multicolumn{1}{c}{ Famili } & $\begin{array}{c}\text { Sawah } \\
\text { Organik }\end{array}$ & $\begin{array}{c}\text { Sawah } \\
\text { Konvensional }\end{array}$ \\
\hline 1. & Entomobryidae & 47,23 & 13,33 \\
2. & Paronellidae & 12,70 & 3,30 \\
3. & Isotomidae & 7,07 & 2,03 \\
4. & Hypogastruridae & 7,60 & 6,20 \\
5. & Sminthuridae & 0,73 & 1,23 \\
6. & Dicyrtomidae & 0,17 & 0,0 \\
7. & Bourletiellidae & 0,53 & 0,0 \\
\hline \multirow{2}{*}{ Total kemelimpahan } & & 76,03 & 26,09 \\
\hline
\end{tabular}


Tabel 4. Jenis-jenis famili dan jumlah famili relatif (\%) arthopoda nir Collembola yang diperoleh dari perangkap pitfall dan Berlese pada lahan sawah organik dan konvensional

\begin{tabular}{|c|c|c|c|c|}
\hline \multirow[b]{2}{*}{ No. } & \multirow[b]{2}{*}{ Famili } & \multirow[b]{2}{*}{ Ordo } & \multicolumn{2}{|c|}{ Jumlah Famili Relatif (\%) pada : } \\
\hline & & & $\begin{array}{c}\text { Sawah } \\
\text { Organik }\end{array}$ & $\begin{array}{c}\text { Sawah } \\
\text { Konvensional }\end{array}$ \\
\hline 1 & Carabidae & Coleoptera & 6,06 & 2,07 \\
\hline 2 & Scarabaeidae & Coleoptera & 0,49 & 3,10 \\
\hline 3 & Staphylinidae & Coleoptera & 6,84 & 5,34 \\
\hline 4 & Cucujidae & Coleoptera & 1,47 & 0,34 \\
\hline 6 & Coccinellidae & Coleoptera & 17,79 & 12,39 \\
\hline 7 & Araneidae & Araneae & 0,59 & 3,96 \\
\hline 8 & Lycosidae & Araneae & 11,14 & 8,78 \\
\hline 9 & Thomisidae & Araneae & 1,17 & 0,86 \\
\hline 10 & Linyphidae & Araneae & 1,66 & 4,13 \\
\hline 11 & Euphtericaridae & Acarina & 7,92 & 0,00 \\
\hline 12 & Braconidae & Hymenoptera & 1,56 & 5,51 \\
\hline 13 & Chalcididae & Hymenoptera & 0,00 & 0,69 \\
\hline 15 & Bombidae & Hymenoptera & 1,37 & 1,38 \\
\hline 16 & Mymaridae & Hymenoptera & 2,44 & 0,34 \\
\hline 17 & Formicidae & Hymenoptera & 10,85 & 20,31 \\
\hline 18 & Acrididae & Orthoptera & 5,18 & 4,48 \\
\hline 19 & Gryllidae & Orthoptera & 0,88 & 2,75 \\
\hline 20 & Gryllotalpidae & Orthoptera & 0,00 & 0,17 \\
\hline 21 & Anajapygidae & Diplura & 1,56 & 0,17 \\
\hline 22 & Aphididae & Homoptera & 0,98 & 2,24 \\
\hline 23 & Delphacidae & Homoptera & 0,10 & 0,00 \\
\hline 24 & Anthomyiidae & Diptera & 6,06 & 14,63 \\
\hline 25 & Cecidomiidae & Diptera & 1,56 & 1,72 \\
\hline 26 & Rhagionidae & Diptera & 1,47 & 0,00 \\
\hline 27 & Rhinotermitidae & Isoptera & 0,00 & 3,27 \\
\hline 28 & Pyralidae & Lepidoptera & 0,00 & 0,17 \\
\hline 29 & Hydrometridae & Hemiptera & 0,49 & 1,20 \\
\hline 30 & Pentatomidae & Hemiptera & 0,10 & 0,00 \\
\hline 31 & Veliidae & Hemiptera & 10,26 & 0,00 \\
\hline \multicolumn{3}{|c|}{ Indeks Keragaman (H') } & 2,75 & 2,61 \\
\hline \multicolumn{3}{|c|}{ Indeks Kemerataan (E) } & 0,78 & 0,77 \\
\hline
\end{tabular}

arthropoda tanah. Hal ini terlihat dari kemelimpahan dan keragaman arthropoda tanah yang cukup tinggi pada lahan organik.

Pada ekosistem yang memiliki kemelimpahan dan keragaman organisme yang tinggi, di dalamnya terdapat interaksi yang kompleks dalam hal jaringjaring makanan yang dapat menunjang stabilitas ekosistem (Price, 1997). Hal ini sesuai dengan apa yang telah diutarakan oleh Odum (1971), bahwa pada ekosistem yang stabil umumnya terdapat kompleks organisme dengan diversitas yang tinggi. Hasil pengamatan menunjukkan bahwa lahan sawah pada masa bera memiliki susunan trofik yang baik. Proporsi arthropoda herbivora cukup rendah, 
Tabel 5. Populasi dan proporsi arthropoda pada lahan sawah organik dan konvensional berdasarkan peranannya

\begin{tabular}{lcccc}
\hline \multirow{2}{*}{\multicolumn{1}{c}{ Peranan }} & \multicolumn{2}{c}{ Sawah organik } & \multicolumn{2}{c}{ Sawah konvensional } \\
\cline { 2 - 5 } & $\begin{array}{c}\text { Populasi } \\
\text { (ekor/perangkap) }\end{array}$ & $\begin{array}{c}\text { Proporsi } \\
(\%)\end{array}$ & $\begin{array}{c}\text { Populasi } \\
\text { (ekor/perangkap) }\end{array}$ & $\begin{array}{c}\text { Proporsi } \\
(\%)\end{array}$ \\
\hline Arthropoda herbivora & 2,64 & 2,43 & 2,36 & 5,96 \\
Arthropoda predator & 19,00 & 17,48 & 9,53 & 24,04 \\
Arthropoda parasitoid & 1,14 & 1,05 & 1,05 & 2,66 \\
Arthropoda lainnya * & 85,90 & 79,04 & 26,69 & 67,34 \\
\hline Jumlah & 108,68 & 100,00 & 39,63 & 100,00 \\
\hline
\end{tabular}

*Arthropoda ini didominasi oleh Collembola (76,03 ekor/perangkap pada sawah organik dan 26,09 ekor/perangkap pada sawah konvensional).

sedangkan arthropoda predator menduduki proporsi yang lebih tinggi (Tabel 5). Berbagai famili arthropoda seperti Coccinellidae, Staphylinidae, Carabidae, Formicidae, Hydrometridae, Veliidae, dan berbagai jenis laba-laba merupakan kelompok arthropoda predator. Collembola dan beberapa famili arthropoda yang lain berperan sebagai dekomposer atau sebagai penyerbuk.

Pada lahan sawah organik di masa bera, arthropoda predator ditemukan dalam jumlah yang cukup tinggi, meskipun pada saat itu jumlah arthropoda herbivora sebagai mangsanya sedikit. Di sini terlihat bahwa keberadaan Collembola dengan kemelimpahan yang cukup tinggi bukan hanya berperan penting sebagai organisme pengurai, tetapi juga sebagai penyangga (buffer) untuk mempertahankan kehidupan arthropoda predator. Selain hal itu rendahnya populasi Collembola mengindikasikan menurunnya kualitas agroekosistem di antaranya dalam hal berkurangnya jenis-jenis musuh alami hama, menurunnya populasi organisme pengurai, serta kemungkinan telah terjadinya pencemaran oleh pestisida pada habitat tersebut.

\section{SIMPULAN}

Penelitian terhadap keragaman dan kemelimpahan Collembola serta arthropoda tanah di lahan sawah organik dan konvensional pada saat bera di Kecamatan Pagelaran Kabupaten Tanggamus ini memberikan simpulan hal-hal sebagai berikut:

(1) Kemelimpahan populasi Collembola pada lahan sawah organik lebih tinggi daripada lahan sawah konvensional, tetapi keragaman jenisnya tidak berbeda. Entomobryidae adalah famili dengan kemelimpahan tertinggi baik pada lahan sawah organik maupun lahan sawah konvensional.

(2) Keragaman dan kemelimpahan arthropoda tanah pada sawah organik lebih tinggi daripada sawah konvensional. Pada masa bera kemelimpahan populasi arthropoda pada sawah organik maupun konvensional didominasi oleh dekomposer (Collembola), selanjutnya diikuti oleh arthropoda musuh alami (predator dan parasitoid). Arthropoda herbivor terdapat pada aras populasi yang rendah.

\section{SANWACANA}

Penulis menyampaikan terimakasih kepada Bapak Sariman yang telah mengizinkan lahannya sebagai tempat penelitian, dan Saudara Farhan Taha, SP. atas kerjasamanya dalam penelitian ini. Ucapan serupa juga disampaikan kepada Dr. Hamim Sudarsono, Dr. F.X. Susilo, dan Ir. Titik Nur Aeny, M.Sc. atas masukan-masukan yang amat berharga.

\section{DAFTAR PUSTAKA}

Anggoro, T. 2003. Pengembangan Pertanian Organik. Tesis. Program Pasca Sarjana Ilmu Lingkungan. Universitas Indonesia. Jakarta..

Anonim. 2007. The Order Collembola. http://www. earthlife.net/insects/collembo. Diakses 20 September 2007. 
Borror, D.J., C.A. Triplehorn, \& N.F. Johnson. 1989. An Introduction to The Study of Insects. $6^{\text {th }}$ Edition. Saunders College Publishing; Holt Rinehart \& Winston. Inc. New York.

Endlweber, K., M. Schadler \& S. Scheu. 2006. Effects of foliar and soil insecticide applications on the collembolan community of an early set-aside arable field. Applied Soil Ecology 31(1\&2): 136-146.

Fountain, M.T., V.K. Brown, A.C. Gange, W.O.C. Symondson \& P.J. Murray. 2007. The effects of the insecticide chlorpyrifos on spider and collembola communities. Pedobiologia 51 (2): 147-158.

Greenslade, P., L. Deharveng, A. Bedos, \& Y.R. Suhardjono, 2000. Handbook to Collembola of Indonesia. Advisor Willem N. Ellis. Museum Zoologicum Bogoriense. Bogor.

Hadley, D. 2007. Order Collembola. http://www. insect.about.com/od/springtails. Diakses 20 September 2007.

Kanal, A. 2004. Effects of fertilisation and edaphic properties on soil-assosiated Collembola in crop rotation. Agronomy Research 2(2): 153168.
Krebs, C. J. 1985. Ecology: The Experimental Analysis of Distribution and Abundance. Harper \& Raw Publisher. New York.

Odum, E. P. 1971. Fundamentals of Ecology. Third Edition. Saunders Company. Philadelphia and London.

Ponge, J.F., S. Gillet, F. Dubs, E. Fedoroff, L. Haese, J.P. Sousa \& P. Lavelle. 2003. Collembolan communities as bioindicators of landuse intensification. Soil Biology and Biochemistry 35: $813-826$.

Price, P.W. 1997. Insect Ecology. $3^{\text {rd }}$ Edition. Wiley Interscience. New York.

Scott, H. G. \& C. J. Stojanovich. 1982. Arthropods of Public Health Importance: Key to Common Classes and Orders. U. S. Department of Health Education and Welfare. Communicable Diasease Center, Training Branch. Atlanta, Georgia.

Trewavas, A. 2007. Organic Farming in Perspective. http://www.agbioworld.org./argfarmperspec tive.html. Diakses. 22 September 2007. 